\title{
DISTRIBUTION AND DEVELOPMENT OF THE WORLD'S PEAT DEPOSITS
}

$\mathrm{T}$ HE first International Peat Congress was arranged under the auspices of Bord na Mona in Dublin in 1954. Subsequent efforts to hold a second congress were abortive until the Soviet authorities agreed in 1962 to organize it in Leningrad during August 15-22, 1963. The country and venue were most appropriate since the U.S.S.R. possesses more than 60 per cent of the world's estimated peat deposits and more than 70 per cent of the world output of peat, peat products and their agricultural and industrial applications.

More than 700 scientists attended, including academicians and technologists, from 26 different countries, including nearly every European country, the U.S.S.R. and its associated Republics, the United States, Canada and Cuba. Delegates were welcomed at the inaugural session on behalf of the Soviet authorities and the City of Leningrad. Many national reports were presented summarizing the geography and development of the peat resources of individual countries. Variety was the keynote. Peat claimed some degree of primary significance in countries such as the U.S.S.R., the Irish Republic, the United States, Finland, Denmark, Norway, Sweden, West Germany, the German Democratic Republic, Poland, Holland and Canada, where peat resources were either extensive per se or relatively extensive as a proportion of national territory, or especially significant because of the relative lack of, for example, coal deposits or other fuels. On the other hand, peats were localized and of relatively secondary significance in such countries as Cuba, Israel, Italy, Britain and Roumania, either because of their limited occurrence or because other sources of fuel and power, for example, coal, had overshadowed their development.

Afterwards four separate sections arranged concurrent sessions for paper-reading and general discussions. The sections were concerned with: (1) genesis, stratigraphy and geography of peat deposits (28 papers); (2) winning and processing of peat ( 30 papers); (3) utilization of peat and peat deposits in agriculture (31 papers); (4) peat physics and chemistry, chemical technology and balneological use of peat ( 27 papers) Thus, in all, 116 papers were presented.

In Section 1, four chairmen presided, S. Tyuremnov (U.S.S.R.), E. Kivinen (Finland), S. Schneider (Bulgarian Democratic Republic) and A. Olenin (U.S.S.R.). The distribution and classification of peats in the British Isles were discussed by A. J. Howard (Northern Ireland), R. A. Robertson (Scotland), J. A. Taylor (Wales) and A. J. P. Gore (England). Table 1 shows the relative distribution of the world's peat resources in relation to individual countries.

More than half $(60.7$ per cent) of the world's peat is concentrated in the U.S.S.R., not only in the Leningrad region but also in those lands lying broadly south-east of the Ural Mountains and north-east of the Caspian Sea. Finland claims 8.2 per cent of the world's peat. On average about 32 per cent of the land area of that country is bog -one Finnish hectare in three. In northern Finland the average approaches 41 per cent, in southern Finland about 24 per cent. In places in the far north more than 60 per cent of the land is covered by peat. Clearly, the boglands of Finland are a resource both as land area and as peat. Consequently, research into peat materials, and the reclamation and management of peatland, are well matured. An interesting paper delivered by B. Y. Pessi ${ }^{1}$ described the effects of the addition of mineral soil on the temperature conditions of cultivated peat land.

Temperature changes although small $\left(1^{\circ}-3^{\circ} \mathrm{C}\right.$, but occasionally up to $6^{\circ} \mathrm{C}$ ) have been shown to be statistically and ecologically significant. J. A. Taylor ${ }^{2}$ has undertaken similar work on south-west Lancashire mossland by applying marl (local boulder clay) at the traditional Lancashire rates of 100-200 tons per acre on specially prepared and triplicated plots. Preliminary results show temperature increases of a similar magnitude to those quoted by Pessi, and they are especially manifest during high and late summer, namely, June-September. This is not to underestimate the chemical and physical and ultimately biological changes induced by adding calcareous marl, but a parallel modification of the temperature régime also occurs.

Canada, with 7.8 per cent, occupies third position in the international list. Much of the Canadian bogland is uninhabited and unexploited. A valuable paper given by N. B. Radforth ${ }^{3}$ dealt with the methods and results of an aerial survey of so-called 'organic-terrain' in Canada. Some 250,000 acres have been surveyed and it is estimated. that they could produce 200 million tons of peat fuel and 15 million tons of peat material for other purposes. However, the availability of superior sources of fuel meant that commercial use of peat fuel is virtually nil and the major uses of peat are in agriculture and horticulture. Of considerable academic interest, however, are the investigations of organic terrain by interpretation of photographs taken from the air, especially in environmental engineering with particular reference to problems of transportation of peat-land.

In the United States (6.2 per cent), more than two-thirds of peat production is concentrated in California, Indiana, Michigan and Washington. Specially adapted mechanized methods have been developed, the peat being largely used for soil improvement in gardens, nurseries and greenhouses. Marketing includes specially arranged prepacking. Future expansion of the markets will be restricted to agriculture and horticulture since the reserves of coa\}, oil and natural gas are so large.

Table 1. World Peat Resources (estimated)*

Country

(1) U.S.S.R.

(2) Finland

(3) Canada

(4) United States (without Alaska)

(5) Germany (East and West)

Great Britain and
Irish Republic

(7) Sweden

(8) Poland

(9) Indonesía

(10) Norway

(12) Icelan

(14) Jew Zealand

(15) Denmark

(16) Italy

(17) France

(18) Hungary

(19) Netherlands

(20) Argentina

(21) Roumania

(22) Czechoslo

(23) Austria

(25) Spain

(26) Others Total
(11) Cuba

\begin{tabular}{|c|c|}
\hline $\begin{array}{l}\text { Per cent of } \\
\text { world } \\
\text { resources }\end{array}$ & $\begin{array}{l}\text { Total arest } \\
\text { in million } \\
\text { hectares }\end{array}$ \\
\hline $\begin{array}{r}60 \cdot 7 \\
8 \cdot 2 \\
7 \cdot 8 \\
6 \cdot 2 \\
4 \cdot 3\end{array}$ & $\begin{array}{c}73 \\
10 \\
9 \cdot 5 \\
7 \cdot 5 \\
5 \cdot 25\end{array}$ \\
\hline $\begin{array}{l}4 \cdot 3 \\
4 \cdot 1 \\
1 \cdot 3 \\
1 \cdot 1 \\
0 \cdot 7 \\
0 \cdot 4 \\
0 \cdot 26 \\
0 \cdot 18 \\
0 \cdot 14 \\
0 \cdot 01 \\
0 \cdot 01 \\
0 \cdot 01 \\
0 \cdot 08 \\
0 \cdot 041 \\
0 \cdot 041 \\
0 \cdot 041 \\
0 \cdot 025 \\
0 \cdot 018 \\
0 \cdot 013 \\
0 \cdot 005 \\
0 \cdot 026\end{array}$ & $\begin{array}{l}5.25 \\
5.0 \\
1.5 \\
1.35 \\
1.0 \\
0.45 \\
0 \cdot 3 \\
0 \cdot 2 \\
0 \cdot 165 \\
0.12 \\
0.12 \\
0.12 \\
0.1 \\
0.045 \\
0.045 \\
0 \cdot 045 \\
0.30 \\
0.022 \\
0.015 \\
0 \cdot 006 \\
0.03\end{array}$ \\
\hline $100 \cdot 0$ & $121 \cdot 433$ \\
\hline
\end{tabular}

*These figures have been estimated from sources made available in papers and exhibits at the Congress. They are all estimates and in general tend to be conservative. It is likely that future surveys will extend the list of countries and increase selected national proportional areas so as to create
larger global total. 
Substantial peat deposits exist in both East and West Germany $(4 \cdot 3$ per cent in all), and significant contributions have been made to the academic classification of bogs into high, intermediate and low types and to the mechanized methods of peat-winning, in particular for horticulture. Peat products, that is, peat mixed with organic waste, earth or mineral fertilizer, have been extensively introduced. Peat is also used in medicine and as a source of activated coal.

In Great Britain (4.3 per cent), the Highland zone and its marginal lowlands, for example, in Lancashire, Shropshire and Somerset, monopolize much of both the hill peat and lowland bogs with the major exception of the East Anglian Fenlands. The intensive agricultural appropriation of the latter and the relative insignificance of peat deposits in England, both areally and economically, are reflected in the fact that no official delegate for England was nominated for the Congress. A. J. P. Gore (the Nature Conservancy $)^{4}$ dealt with the comparative ecology of peats at different elevations in the Pennines, and both R. A Robertson (the Macaulay Institute for Soil Research) and J. A. Taylor referred, where appropriate, to English peats in the course of their papers on Seotland and Wales respectively. The reports of the Scottish Peat Committee for 1954 and 1962 have summarized the evidence and indicated the possibilitios of development ${ }^{5}$. The peat survey has been concerned to obtain data for the area, depth and solids content of the major bogs, and to investigate the physics and chemistry of the peat types. So far, 103,000 acres $(42,000$ hectares) have been covered, of which 77,000 acres $(31,000$ hectares) are located in the Highlands and Islands where the bulk of Scottish peats occur. The remainder includes such bogs as Flanders Moss (4,000 acres) in Perthshire, Airds Moss (3,800 acres) in Ayrshire and Lochar Moss (4,800 acres) in Dumfriesshire. Although many of these deposits are suitable for exploitation as fuel, large-scale industrial development is by no means imminent and energies will be concentrated on scientific investigations of the peat deposits with reference to the realization of their maximum potentialities for agriculture, horticulture and afforestation. For example, judging by comparative costs in Ireland, electricity could be produced, using steam, for generation and milled peat and/or de-watered peat for fuel, but a subsidy of $0.45 d$. per unit would be needed to enable peat to survive competition with coal, oil, hydro-electric power and nuclear energy. Again, peat-briquettes could only supplement the household fuel market in Scotland. On the other hand, Scotland supplies less than one-third of the annual output of peat for horticulture and moss litter (80,000 tons per annum) and could supply more. At present some 14,000 tons is imported from Ireland annually. The techniques of afforesting peat-land have been investigated and developed by the Forestry Commission ${ }^{6}$. Reclamation of peat-land in situ for agriculture gives good agricultural land eventually, but the costs and delay are normally beyond the scope of the individual farm turn-over.

In Wales, Taylor ${ }^{7}$ has concluded that in reviewing the historical and contemporary significance of Welsh peats, the academic, scientific, afforestation and conservational interests dominate over commercialization both of agricultural and industrial potentialities. Quaternary research in Wales has lagged behind that in Southern Ireland and East Anglia when glacial and interglacial chronologies have boen calculated. Generalized hypotheses such as those expounded by Mitchell $^{8}$ require local testing. The investigations of Bartley ${ }^{9,10}$, Watson ${ }^{11}$, Seddon $^{12}$, Wood ${ }^{13}$, Taylor ${ }^{14}$ and Stewart ${ }^{15}$ are notable here. Again Borth Bog has recently become the scene of reclamation for arable cropping to an extent which might well prevent this unique coastal raised bog from reaching its fullest maturity and which will, without doubt, induce drainage changes, which will in turn eause floral and faunal adaptations. The point of viow of the conservationist is well demonstrated here, and the point was sympathetically received at the Congress when Taylor presented his paper?

In Ireland peat is classed as a national resource. Bord na Mona, a statutory corporation, was established by the Irish Government in 1946 to develop Irish bogs for peat fuel and horticultural peat. It is financed by means of interest-bearing repayable advances. Up to 1963 a total expenditure of $£ 24$ million has been authorized. Dwyer ${ }^{16}$ has indicated the distribution of Irish peat-land which is conspicuously central and west central and west coastal in location. Five of seven planned power stations using peat are already functional. Total capacity will be $427 \cdot 5 \mathrm{MW}$. The Board also operates three peat-briquetting plants. At the height of the production some 7,000 men are employed. Sod-turf is being used to make activated carbon and milled turf is being adopted as a foundry mix ingredient and as an additive to coal to produce smokeless fuels. Research is proceeding into the fermentation of turf to extract high bulk value chemicals. A recent effective solution to the exposure of peat stocks to the Irish weather is to cover them with special polyethylene films made to measure. Clearly, both traditionally and in terms of present economic problems, the bogs of Ireland have, and will have, a national part to play in any programme for revitalization, re-population and industrialization of rural Ireland both within reach of Dublin and farther west. The work being carried out at Glenamoy by P. J. O'Hare et al. ${ }^{17}$ points the way to the future.

One interesting feature emerging from the international assessment of the geography of peat deposits concerns their average maximum depth. Most sources quote $30-35 \mathrm{ft} .(9-11 \mathrm{~m})$ and occasionally $40 \mathrm{ft}$. $(12 \mathrm{~m})$, but the representative from Greece reported a figure of $98 \mathrm{ft}$. $(30 \mathrm{~m})$ and certain tropical peaty swamps in Borneo are alleged to attain depths of $60 \mathrm{ft}$. $(18 \mathrm{~m})$. These extreme figures normally rofer to the centres of basin peats or raised bogs in concave sites. For extensive peat-lands of the blanket bog-type colated on flattish plain or plateau country average maximum depths are in the range of 6-12 ft. and sometimes $20 \mathrm{ft}$. (2-4 and sometimes $6 \mathrm{~m}$ ).

For details of peat deposits and their developments in the other countries reference may be made to the Proceed ings and Transactions of the Congress which, subject to adequate demand, will be published in due course at a cost of about $£ 5$. Similar reference may be made to the work of Sections 2, 3 and 4 of the Congress for which only brief summaries can be included here.

Section 2 on the winning and processing of peat had five chairmen as follows: A. Sokolov (U.S.S.R.), D. Lawlor (Ireland), J. Filipowicz (Poland), O. Uddgren (Sweden) and N. Ivashechkin (U.S.S.R.). Special attention was directed to machinery for peat collecting and peat processing. Visits to the peat-fired power station at Dubrov sky, $60 \mathrm{~km}$ from Leningrad, and to the Zaplyusski peat deposit within the Leningrad Region were most illuminating. At Dubrovsky, observations were made on unloading mechanisms, fuel stocking, sample extraction and analysis, peat firing in the fire-chamber, ash and slag removing, and dependence of the working rate on the peat quality. At Zaplyusski, the study tour included methods of mechanical tree-clearance, tree-stripping, ground preparation, drainage and preparation of the peat-bog; methods of peat winning, drying, collecting, loading and transportation, including a specially adapted bog railway system which could lay its own track as required within the reclamation programme. Papers delivered at the indoor sessions included roforence to turf-firing in steam-boiler installations, processes in peat-briquette manufacture, peat compression and do-watering thcory, peat litter and the efforts of drainage control on the hydrological balance of bogs.

Section 3 was supervised by five chairmen: S. Dragunov, (U.S.S.R.), R. Lucas (United States), W. Baden (East Germany), S. Prat (Czechoslovakia) and L. Khristova (U.S.S.P.). The theme was the use of peat and peat 
deposits in agriculture. A visit to Prigorodni State Farm (of 2,700 hectares), near Leningrad, revealed that experiments in the application of peat in agriculture were at an early stage. Even allowing for the latitude and relatively poor sandy podzolized soils of the region, production figures quoted were relatively low both per hectare and per man. Selected topics discussed at the Congress itself were humic fertilizers and their effect on plant metabolism, the making of composts from peat and pig excrements, trace element deficiencies so characteristic of bog soils, long-term effects of peat fertilizers on yield and quality of plant, use of peat fertilizers in afforestation, and the effects of the penetration of plant cells by humic sub-
stances.

In Section 4 on peat physies and chemistry and peat balneology, that is, its use in medicine, there were four chairmen, M. Volorovich (U.S.S.R.), R. Kadner (East Germany), A. Sundgren (Finland) and I. F. Prado (Cuba). Themes examined included types of peat fuel, the cokability of various compressed peat products, the constitution of peat wax as separated by column chromatography, cation exchange capacities of peat, the manufacture of water-gas from milled and powdered peat, the extraction and composition of peat-bitumens, the problem of humic substances bound differentially in a colloidal complex, and observations on autothermal peat dust gasification experiments on an industrial scale. The application of peat and associated muds in balneology were demonstrated by data from Munich, Neydharting (Austria), and various parts of the U.S.S.R. including Sochi on the Black Sea coast. This was substantial evidence of partial success in demonstrating the curative effects of peat and bog-muds for certain types of disability or disease in human beings. The Soviet authorities are to be congratulated on their hospitality and energy in organizing this second Congress which enabled valuable interchange of ideas and methods. It is to be hoped that the time-interval between the second and the third Congress will be less than that between the first and the second.

J. A. TAYLOR

'Pessi, B. Y., "On the Effect of Addition of Mineral Soils on Temperature Conditions of Cultivated Peatland". Second Intern. Peat Congress, Leningrad, U.S.S.R., August 1963.

"Taylor, J. A., "Marling Experiments to Measure the Modification of Soil Temperature Regimes and Relative Productivity of Lancashire Mosslands". Welsh Soils Discussion Group, Report No. 4 (in the press).

${ }^{3}$ Radforth, N. B., "The Principles of Airphoto Interpretation as Related to Organic Terrain". Second Intern. Peat Congress, Leningrad, U.S.S.R. August 1963.

4 Gore, A. J. P., "Comparative Ecological Studies on Peats at Two Different Altitudes in Northern England". Second Intern. Peat Congress, Leningrad, U.S.S.R., August 1963.

${ }^{5}$ Scottish Peat Committee, Report No. 1, Scottish Home Dept. (H.M.S.O. Edinburgh, 1954). Report No. 2, Dept. of Agriculture and Fisheries for Scotland (H.M.S.O., Edinburgh, 1962).

- Forestry Commission, Experiments in Tree Planting on Peat. Bulletin No. 22 (H.M.S.O., 1954).

"Taylor, J. A., "The Peat Deposits of Wales". Second Intern. Peat Con-

gress, Leningrad, U.S.S.R., August 1963.
${ }^{8}$ Mitchell, G. F., Adv. Sci., 17, $313(1960)$.

- Bartley, D. D., J. Ecol., 48, 205 (1960).

${ }_{10}$ Bartley, D. D., New Phytol., 59, 238 (1960).

11 Watson, E., Periglacial Action in the Uplands of Mid-Wales. Report S.,. of the Welsh Soils Discussion Group, 11 (1962).

${ }^{18}$ Seddon, Phil. Trans. Roy. Soc. London, Series B, No. 716, 244, 459 (1962). ${ }^{13}$ Wood, A., Geog. J., 128, Pt. 1, 301 (1962).

${ }^{24}$ Taylor, J. A., Report No. 2 of the Welsh Soils Discussion Group, $2 \theta$ (196:2). ${ }^{15}$ Stewart, V. I., Report No. 2 of the Welsh Soils Discussion Group, 19 (1962). ${ }^{16}$ Dwyer, D. J., Geog. J., 128, Pt. 2, 184 (1962).

17 Walsh, T., O'Hare, P. J., and Quinn, E., Adr. Sci..14. 405 (1958).

\section{ANTIMICROBIAL AGENTS AND CHEMOTHERAPY}

$\mathrm{T}$ HE third Interscience Conference on Antimicrobial Agents and Chemotherapy was held in the Mayflower Hotel, Washington, D.C., under the sponsorship of the American Society for Microbiology during October 28-30, 1963. Registered attendance at this meeting reached 825 , a much larger number than that attending the second Conference in Chicago in November 1962. Foreign participants included a group of 12 from Japan, 16 from Canada, 6 from England, as well as scientists from 17 other countries.

The three-day Conference was opened with a greeting from J. R. Porter, president of the American Society for Microbiology, and an address on "Recent Legislation and the Development of New Drugs", by W. B. Rankin, assistant commissioner of food and drugs, Food and Drug Administration, Department of Health, Education and Welfare. Among the features of the Conference were five symposia including: (1) "Chemistry of Antibioties" (convened by C. P. Schaffner), with discussions of ehemical aspects of the synthesis of tetracycline by $H$. Muxfeldt, the structure of viomycin by J. R. Dyer, the structure of streptolydigin by K. L. Rinehart, fatty acids from aspartocin by W. K. Hausmann, and the structure of vernamycin $B$-type antibiotics by M. Ondetti; (2) "Infections Presenting Special Problems in Chemotherapy" (convened by W. L. Hewitt), with discussions of chemotherapy of staphylococcal infections by $\mathbf{M}$. Hamburger, management of Gram-negative bacillary infections of the gastrointestinal and central nervous systems by P. F. Wehrle and infections in association with malignancy by $J$. P. Sanford; (3) "Side Reactions Attributed to Antimicrobial Agents" (convened by H. F. Dowling), with discussions of immunochemical basis for penicillin allergy by C. W. Parker, damage to the eighth nerve associated with antibiotic therapy by Martha $D$. Yow, reactions to antibiotics -blood dyscrasias by C. M. Huguley, and clinical experi- ence with the use of potentially nephrotoxic antibiotics in the treatment of infections in uræmic patients by C. M. Kunin; (4) "Mode of Action of Antibioties" (convened by $D$. Perlman), with summaries on penicillin by J. T. Park, streptomycin by C. Hurwitz, polyene antifungal agents by S. C. Kinsky, and erythromyein by S. B. Taubman; (5) "Antimicrobials in Veterinary Medicine" (convened by C. G. Durbin), with papers on antibiotics as anthelmintics by R. F. Shumard, antibiotics and antimicrobials in therapy of fish diseases by $\mathrm{K}$. Wolf, and special antibiotic preparations for veterinary use by I. S. Rossof.

Among the new antibioties announced at the meeting were: gentamicin, antibiotic $M S D-235$, doricin, $L L$ $A E 705 W, L L-A M 684 B, M S D-92$, and anthricidins $A$ and $B$. The cytotoxic and anti-tumour substances described included: $B A-17039-A$ and $B, B A-90912, B A$ 181314, septacidin and peliomycin. An informal session heard S. A. Waksman discuss problems of nomenclature of antibiotics, and the chairman was instructed to request that the American Society for Microbiology form a group to consider this problem.

Clinical reports were presented on the effectiveness of the following antibiotics: gentamicin; lincomycin; aminosidin, cephalothin, naphthcillin, methicillin, cloxacillin, ampicillin and oxacillin. Papers on the following antimicrobial agents were also on the programme: sulphamethoxazole, 2-methoxy-4-sulphanilamidoquinazoline, 1 (5-nitro-2-furyl)-2-[5-amino-2-(1,3,4-thiadiazolyl)] ethylene,1-(5-nitro-2-furyl)-2-(6-amino-3-pyridazyl)-ethylene, $N$-(5nitrofurfurylidone)-1-amino-2-imidazolidinone, 2,4,5-trichlorophenyl- $\gamma$-iodopropargyl ether, 'Salvizol', and 2 '. deoxy-5-iodouridine.

One day of the conference was devoted to discussions of topics in infectious diseases. Among these were: bacterial endotoxins; anti-Pasteuvella pestis factor, anti- 